Pawet Adam Makowski

Wyższa Szkota Kultury Społecznej i Medialnej w Toruniu

\title{
In the Light of John Paul II's Teaching: Diplomacy's Moral Duty is Respect for Human Rights ${ }^{1}$
}

Human rights hold an important place in Pope John Paul II's teaching to diplomats. The dignity of the human person serves as the basis for the pope's reflection on human rights. In his teaching, the pope taught diplomats how to understand, comprehend, and explain human rights. This publication aims to show in light of Pope John Paul II's teaching that respect for human rights is a moral duty of diplomacy. For the pope, respect for human rights is, on the one hand, an appropriate platform for dialogue with the world and, on the other hand, a way to introduce Christian values into modern culture. John Paul II respected all diplomatic activities aimed at promoting human rights.

Key words: human rights, diplomacy, John Paul II.

\section{Introduction}

Human rights have an important place in John Paul II's teachings to diplomats. The dignity of the human person is the basis for the Pope's reflection on human rights. In New York City on October 2, 1979, John Paul II clearly expressed this view in his Message to the United Nations, stating: "Every analysis must necessarily start from the premise 
Catholic social teaching

that [...] every human being is endowed with a dignity."2 In addition, in his address to the Secretary General of the United Nations, he stressed that: "It is in this dignity of the person that human rights find their immediate source. And it is respect for this dignity that gives birth to their effective protection." 3 In his teaching to diplomats, the Pope presented how one should understand, recognize, and explain human rights. ${ }^{4}$ This publication aims to show that respect for human rights is a moral duty of diplomacy by first discussing human rights violations in the modern world, and then presenting the innate character of human rights. The article will end with individual diplomats' reflections in response to papal teaching in this area.

\section{Human Rights Violations}

In his teaching to diplomats, John Paul II speaks of human rights violations that occur in the modern world. This section will present the most important threats to human rights according to John Paul II, including social, economic, and political tensions; various types of conflict; and the unjust distribution of material goods.

\section{Social, Economic, and Political Tensions}

The first threat to human rights that Pope John Paul II pointed out is tensions that occur within nations and between states, which are the result of a lack of dialogue, understanding, and mutual cooperation with regard to social, economic, and political matters. ${ }^{5}$

When speaking to the Diplomatic Corps in 1982, John Paul II pointed out the tense situations in the countries of Central America caused

2 John Paul II, Address to the General Assembly of the United Nations "Na forum pokoju i sprawiedliwości (10.02.1979)," in Dzieła zebrane Jana Pawta II, Vol. XIV (Cracow: Wydawnictwo M, 2009), 29. Hereafter abbreviated as DZ. In English, see: https://w2.vatican.va/content/john-paul-ii/en/speeches/1979/october/documents/hf_jp-ii_spe_19791002_general-assembly-onu.html.

3 John Paul II, Message to the Secretary General of the United Nations "Wolność religijna podstawą praw ludzkich (12.02.1978)," in DZ, Vol. V (Cracow: Wydawnictwo M, 2009), 286. For the message in English, see: https://w2.vatican. va/content/john-paul-ii/en/messages/pont_messages/1978/documents/hf_jpii_mes_19781202_segretario-onu.html.

$4 \quad$ See. F. J. Mazurek, Prawa człowieka $w$ nauczaniu społecznym Kościoła. Od papieża Leona XIII do papieża Jana Pawta II (Lublin: Redakcja Wydawnictw Katolickiego Uniwersytetu Lubelskiego, 1991), 6.

$5 \quad$ Cf. A. Zwoliński "Wojna," Encyklopedia nauczania społecznego Jana Pawła II (Radom: Wydawnictwo Polwen, 2005), 573-578. Hereafter abbreviated as ENS. 
by difficult social, economic, and political factors. Specifically, the state's repressive actions were inducing citizens to become partisan fighters. ${ }^{6}$ The escalation of these tensions led to numerous conflicts, which, in turn, increased the number of victims, especially within the civilian population. ${ }^{7}$ By comparing the tensions that were occurring in Central America and the Middle East, Pope John Paul II saw that a lack of understanding and dialogue had led to increased aggression and violence that endangered the citizens' safety. ${ }^{8}$

Catholic social teaching

Tensions have also affected the countries of Central and Eastern Europe, including Poland. For example, the violence that swept over Poland led to the declaration of martial law in 1981. During that time, many thousands of people, especially intellectuals and activists involved in freedom movements, were interned. With this in mind, Pope John Paul II pointed out that action based on repression and violence always leads to the moral enslavement of all social milieus. These actions contribute to the violation of fundamental human rights and cause the suffering of thousands of people. ${ }^{9}$

During a meeting with the Diplomatic Corps in 1983, John Paul II did not fail to mention the tensions occurring in Northern Ireland at the time. These tensions were the result of the discord between the social and political circles, which led to human rights abuses and social discontent. In the words of the Pope himself, "The lack of genuine dialogue between the social and political entities implies a seeming passivity that permits human rights violations." 10

John Paul II's statements to diplomats in 1996 reveal that he was aware that relieving tensions in many parts of the world was an extremely difficult task. During his address, John Paul II reminded diplomats that, despite many warnings and appeals, the situation in the

$6 \quad$ One of the oldest forms of combat carried out using conventional weapons. The dictionary defines it as irregular or subversive war (hidden activity that aims at distracting the enemy's attention) against an occupant that is approved by the population. Partisans' aim is to choose their own government. Cf. B. Kaczorowski, Ed., "Partyzantka," Nowa encyklopedia powszechna PWN, Vol. 6 (Warsaw: Wydawnictwo Naukowe PWN SA, 2004), 339.

Cf. John Paul II, Address to the Diplomatic Corps "Kościół wobec największych problemów współczesnego świata (01.16.1982)," in DZ, Vol.V(Cracow:Wydawnictwo M, 2009), 464.

Cf. Ibid.

Cf. Ibid.

10 John PaulII, Address to the Diplomatic Corps "Założenia i cele międzynarodowej działalności Stolicy Apostolskiej (01.15.1983)," in DZ, Vol.V (Cracow: Wydawnictwo M, 2007), 475. 
Catholic social teaching world, particularly in the Middle East, had not improved. Residents in these parts of the world are "being treated without respect and plunged into the greatest distress." 11

When analyzing the issue of national and international tensions, the Pope perceived how they often occur between sovereign states and are the result of a so-called "double polarization." By this term, he meant contrasts between the East and the West, the North and the South, otherwise understood as the disparities between different geographical regions, the unjust distribution of materials goods, and prevailing totalitarian systems. Taken together, these factors often lead to basic human rights violations. According to John Paul II, diplomatic activities should strive to mitigate these disparities and contrasts. Furthermore, he pointed out that the tensions that occur in the modern world are more frequent in East and West than in the North and South. This is due to the fact that a greater number of technology specialists work in the East and West; consequently, economic power, large industries, production capacities, social communication networks, and conventional and nuclear weapons are concentrated in these areas. Tensions in these regions are also more frequent and more dangerous because they are often ideological. Contrasts that lead to tensions between North and South are primarily related to the social backwardness, destitution, and poverty in large parts of populations. ${ }^{12}$

The extent of the tensions present in the modern world reveals the social, economic, and political inequalities and disparities that exist among peoples and nations. For this reason, Pope John Paul II reassured diplomats that the Holy See was not indifferent to the dramatic situations caused by such tensions. Rather, the Church initiated (and continues to initiate) efforts aimed at protecting the good of individuals and nations..$^{13}$ In this way, John Paul II actively participated in international activities to ensure global security and, when doing so, referred to moral norms that are neither ideological nor political. John Paul II was aware that, if emerging tensions are not adequately controlled, then they escalate and evolve into local and international conflicts. ${ }^{14}$

John Paul II, Address to the Diplomatic Corps "Światła i cienie współczesnego świata (01.13.1996)," in DZ, Vol. V (Cracow: Wydawnictwo M, 2007), 579. For the address in English, see: https://m.vatican.va/content/john-paul-ii/en/speeches/1996/january/documents/hf_jp-ii_spe_13011996_diplomatic-corps.html. (01.14.1984)," in DZ, Vol. V (Cracow: Wydawnictwo M, 2007), 484.

Cf. Ibid.

Cf. Ibid. 


\section{Conflicts}

As John Paul II pointed out, conflicts in the world are another threat to human rights, since they escalate tensions between peoples, nations, and states. In turn, this often leads to the use of force, violence, and warfare. ${ }^{15}$ The Pope persuaded diplomats that there is "an even greater moral need than there was in past years for conflicts to be resolved peacefully on the basis of justice." 16

When speaking to the Diplomatic Corps in 1984, John Paul II Catholic social teaching emphasized that "there are ways to resolve various contemporary conflicts." 17 One way to achieve this is by withdrawing troops from occupied territories, since this prepares the ground for political agreement that fosters dialogue, builds up the common good, and respects the sovereignty of each state. ${ }^{18}$ In the same speech, John Paul II also pointed out that diplomacy "cannot turn a blind eye to the numerous unresolved problems, conflicts, and unjust situations that still weigh heavily on the world and remain a challenge that the international community cannot fail to address." 19 These words indicate that it is diplomacy responsibility to respond to the suffering and misery that afflict many millions of people due to ongoing conflicts. In many instances, diplomatic efforts are ineffective. Consequently, according to John Paul II, it is necessary to update diplomatic activities so that they become an increasingly more effective tool to mitigate conflicts. ${ }^{20}$

At his New Year's meeting with the Diplomatic Corps in 1985, the Pope noted that ongoing and unresolved conflicts had spread to other states and were also affecting regions such as the Caucasus, the Russian Federation, and Chechnya. The escalation of conflicts poses a difficult challenge to diplomacy and forces diplomats to take decisive

15 Cf. "Wojna," in ENS, 573-579.

16 John Paul II, Speech given at the headquarters of the International Court of Justice in Hague "O wspólne dobro społeczności międzynarodowej(05.13.1985)," in DZ, Vol. XIV (Cracow: Wydawnictwo M, 2009), 741. For the speech in English, see:https://w2.vatican.va/content/john-paul-ii/en/speeches/1985/may/documents/ hf_jp-ii_spe_19850513_corte-internazionale.html.

John Paul II, "Nie ma dnia do stracenia," 484.

Cf. Ibid.

John Paul II, Speech during a meeting with the Canadian government and the Diplomatic Corps at Rideau Hall "O nową wizję ludzkości (09.19.1984)," in DZ, Vol. XII (Cracow: Wydawnictwo M, 2009), 236.

Cf. Ibid. 

teaching

steps towards their resolution. ${ }^{21}$ In this sense, by posing specific questions about the kind of measures to be taken to ensure the peaceful coexistence of different peoples, Pope John Paul II tried to encourage diplomats to reflect on this issue. More specifically, he emphasized how important it is to negotiate with heads of states, leaders of governments, ambassadors, and representatives of international institutions. According to John Paul II, this is the right way to overcome conflicts, since their causes were and continue to be a lack of coexistence among nations due to ethnic, religious, and linguistic diversity. ${ }^{22}$

During a meeting with the Diplomatic Corps in 1986, the Pope pointed out that, although global conflicts had not occurred since the end of World War II, local conflicts had similar effects on nations and peoples as global conflicts, since these conflicts lead to the death of thousands of people as well as the economic and moral ruin of many societies. ${ }^{23}$ Therefore, using the example of ongoing conflicts in the Mediterranean Sea, John Paul II stressed that "there are still too many hotbeds of conflict, more or less disguised, which keep people under the unbearable yoke of violence, hatred, uncertainty and death." 24 This reveals the need for genuine cooperation in conflict-affected regions in order to ensure their stability and security.

In reference to this cooperation, matters pertaining to national, territorial, and religious identity have been and remain relevant. According to John Paul II, many countries affected by conflict can come to an agreement through dialogue and economic, cultural, and religious cooperation. He believed that this could be beneficial to the peoples living around the Mediterranean and become a model of conduct for others. $^{25}$

Pope John Paul II also recalled the conflict affecting African countries. According to him, the source of their conflict is primarily backwardness and social poverty. He noted that conflicts are not conducive in the fight against hunger, poverty, and disease epidemics, which have decimated African populations, led to even more impoverishment, and

21 Cf. John Paul II, Address to the Diplomatic Corps "Stolica Apostolska jest głosem, na który czeka ludzkie sumienie (01.09.1995)," in DZ, Vol. V (Cracow: Wydawnictwo M, 2007), 573.

Cf. Ibid.

Cf. John Paul II, Address to the Diplomatic Corps "Pokój nie jest możliwy bez solidarności i sprawiedliwości (01.11.1986)," in DZ, Vol.V (Cracow: Wydawnictwo M, 2007), 497.

John Paul II, "Światła i cienie," 579.

Cf. Ibid. 
deprived people of the right to a dignified existence. ${ }^{26}$ According to John Paul II, the creation of the African Union ${ }^{27}$ was a source of hope for the future and will make it possible to develop common principles through which all Member States can unite to overcome conflicts. ${ }^{28}$

During his meeting with the Diplomatic Corps in 2000, the Pope noted that "[c]onflict prevention would avoid situations difficult to resolve and would spare much suffering." 29 In this regard, the Holy Father was convinced that diplomacy has many tools at its disposal to motivate international institutions to be more active and help solve conflicts. Furthermore, based on his statements, it is clear that the pope believed that it is sufficient to use these tools while "carefully distinguishing, without opposition or separation, between politics, law and morality." 30

Existing conflicts entail threats to human rights, and Pope John Paul II believed that every diplomat should keep this reality in mind. Conflicts also undermine the social achievements and cultural heritage of nations by inhibiting their progress. Responsibility for this state of affairs belongs not only to individual governments, but also to the whole international community. This responsibility should be committed to solidarity, so that together nations can seek the interests of all who experience life's tragedies because "all of humanity suffers and is humiliated by the evils which overwhelm one part of its members." 31

$26 \quad$ Cf. John Paul II, Address to the Diplomatic Corps " Nie' śmierci, egoizmowi i wojnie! ‘Tak' życiu i pokojowi! (01.13.2003)," in DZ, Vol. V (Cracow: Wydawnictwo M, 2007), 613.

The African Union is an international organization of a political, military and economic nature that includes all African countries (except Morocco) and was established in place of the Organization of African Unity on July 9, 2002 at the summit in Durban. Its headquarters are located in Addis Ababa, Ethiopia. E. J. Osmańczyk, ed., Encyklopedia ONZ i stosunków międzynarodowych (Warsaw: Wiedza Powszechna, 1986), 556; Encyklopedia spraw międzynarodowych i ONZ (Warsaw: Wydawnictwo PWN, 1974), 3752-3753.

Cf. John Paul II, Address to the Diplomatic Corps "Otwórzmy serca i umysły na wyzwania naszych czasów (01.10.2002)," in DZ, Vol. V (Cracow: Wydawnictwo M, 2007), 610 .

John Paul II, Address to the Diplomatic Corps "Wszyscy jesteśmy odpowiedzialni za wszystkich (01.10.2000)," in DZ, Vol. V (Cracow: Wydawnictwo M, 2007), 599. For the address in English, see https:/w2.vatican.va/content/john-paul-ii/ en/speeches/2000/jan-mar/documents/hf_jp-ii_spe_20000110_diplomatic-corps. html.

Cf. Ibid.

John Paul II, Address to the Diplomatic Corps "Od czego zależy prawdziwy i trwały pokój (01.09.1988)," in DZ, Vol. V (Cracow: Wydawnictwo M, 2007), 513. 
Catholic social teaching

John Paul II pointed out to the diplomats that the states that participate in conflicts often justify their own military actions by claiming righteous defense and unjustified aggression. According to Pope John Paul II, such action can only be justified as a last resort because armed response affects innocent civilians and causes real tragedies. At this point, John Paul II appealed to all people of good will, especially to the powerful and those in diplomatic circles, to strive to come to a broad agreement without compromising any of the parties engaged in fighting. ${ }^{32}$ Resolving global conflicts is an integral part of international life, ${ }^{33}$ and "[e]ach time a conflict breaks out it is the whole world that suffers and is disfigured!" 34 Therefore, as stated before, in the modern world there is an even greater moral obligation to peacefully resolve conflicts by referring to justice and respect for inalienable human rights. ${ }^{35}$

\section{The Unjust Distribution of Material Goods}

The unjust distribution of material goods is another threat to human rights. Material goods are consumer goods necessary for life. They meet people's different needs and allow people to use them to produce other material goods that may be production or capital goods. ${ }^{36}$ During his messages, Pope John Paul II pointed out the need to properly manage material goods. To this end, the principle of justice must take into account the real needs of individual regions and should not be subject to political, administrative, and economic calculations. The just distribution of material goods helps maintain balance among the regions. ${ }^{37}$ Although they often stem from geographic location, historical events, and lack of development of civilization, the inequalities that

For the address in English, see: https://w2.vatican.va/content/john-paul-ii/en/ speeches/1988/january/documents/hf_jp-ii_spe_19880109_corpo-diplomatico. html.

Cf. Ibid.

Cf. John Paul II, Address to the Diplomatic Corps "Stolica Apostolska wobec problemów ludzkości (01.12.1981)," in DZ, Vol. V (Cracow: Wydawnictwo M, 2007), 457.

John Paul II, Meeting with the Diplomatic Corps in Vilnius "Zadania dyplomatów w nowej sytuacji Europy (09.05.1993)," L'Osservatore Romano, Polish Edition 12 (1993): 15. Hereafter abbreviated as OsRomPol. For the speech in English, see: https:/w2.vatican.va/content/john-paul-ii/en/speeches/1993/september/ documents/hf_jp-ii_spe_19930905_corpo-dipl-vilnius.html.
Cf. John Paul II, “O wspólne dobro społeczności międzynarodowej,” 741.
Cf. "Dobra materialne," in ENS, 109.
Cf. John Paul II, Na forum pokoju i sprawiedliwości, 31. 
occur in this area are marked by injustice and social harm. Existing tensions and economic differences between states and continents limit development and violate basic human rights. ${ }^{38}$ Neither of these reasons, however, can justify leaders' lack of efforts to ensure the just distribution of material goods. According to the pope, the proper criterion of justice is essentially humanistic and must promote man's inclusion in a community of persons, which is opposed to collectivism and individualism. ${ }^{39}$ Such action subsequently eliminates various Catholic social forms of injustice, particularly the exploitation of man and corresponds with man's dignity by allowing him to participate in the process of production and in the social life that takes shape around this process. ${ }^{40}$

Addressing the newly appointed Dutch ambassador to the Holy See, John Paul II emphasized that a fair distribution of material resources can only be achieved through actively developing and pursuing policies. ${ }^{41}$ His statement recalls words of Genesis, which says, "Be fruitful and multiply, that you may populate the land, and make it subject to it" (Gen 1:28).

The contrasts that result from the unjust distribution of material goods are most apparent in Latin American countries and on the African continent. According to Pope John Paul II, in these regions, the most important task is set aside all private and group interests in order to reduce differences and prevent them from arising in the future. ${ }^{42}$ The international community should be aware that the gap between rich and poor societies threatens respect for fundamental human rights. The Pope taught that "[t]his must also be said with even greater insistence with regard to the abyss separating countries and regions of the earth. Surely the only way to overcome this serious disparity between areas of satiety and areas of hunger and depression is through coordinated cooperation by all countries." ${ }^{43}$ In turn, this would make it cooperation possible to achieve the authentic good of the entire human family. ${ }^{44}$ Unity between societies and peace in the

$38 \quad$ Cf. Ibid.

39 Cf. "Humanizm chrześcijański," in ENS, 187.

$40 \quad$ Cf. John Paul II, "Na forum pokoju i sprawiedliwości," 31

41 Cf. John Paul II, Address to the new ambassador of Holland "Szacunek dla osoby ludzkiej od poczęcia do naturalnej śmierci (01.22.2005)," OsRomPol 4 (2005): 20 .

$42 \quad$ Cf. John Paul II, “Otwórzmy serca i umysły,” 610.

$43 \quad J o h n$ Paul II, "Na forum pokoju i sprawiedliwości," 32.

44 Cf. John Paul II, Address to the Parliamentary Assembly Committee of the European Council for Relations with National Parliaments "O podstawową 

teaching

world are indispensible for cooperation and achieving the human good; for, according to John Paul II, only these two things can neutralize the differences that exist in these areas..$^{45}$ By returning to the moral values of the Church, it is possible for nations and communities to strengthen this process and work toward true development. Only through giving up that which is unnecessary can a noble and generous servant of the weakest provide them with what they need. ${ }^{46}$

\section{The Inherent Nature of Human Rights}

For John Paul II, the Gospel is the source of knowledge of the inherent nature of human rights. In this regard, the Gospel has a universal dimension and is a profound inspiration to consider in resolving these issues. The second part of this chapter will describe the inherent nature of human rights, their primacy over the laws of the state, and the position of the Holy See regarding the protection of human rights.

Knowing the threats to human rights and seeking ways to overcome them, one cannot overlook the fact that ideas and concepts of human rights have evolved over the centuries. ${ }^{47}$ They have appeared in natural law, theological thought, and the humanities. ${ }^{48}$ The dignity of the human person is the most credible source from which to know the inherent character of human rights. Therefore, human rights are

tożsamość Europy (03.17.1988)," in DZ, Vol. XIV (Cracow: Wydawnictwo M, 2009), 839 .

Cf. John Paul II, “Na forum pokoju i sprawiedliwości,” 32.

Cf. John Paul II, "Otwórzmy serca i umysły," 610.

The idea of human rights has gained wide acceptance. As an expression of the influence of moral norms and legal rights, human rights have become the the rule of international law. Representatives of the West have shared opinions that emphasize the importance of the idea of human rights, and representatives of other cultures are now ascribing to these points of view. Representatives of various cultural backgrounds participated and continue to participate in creating documents about human rights, and these endeavors have been encouraged by the United Nations. The Universal Declaration of Human Rights is referred to in constitutions of not only western countries such as Spain (1978) and Portugal (1989), but also and mainly in developing countries such as Burundia (1992) Chad (1993), Ethiopia (1991), Gabon ( 1991), Guinea (1986), Mali (1992), Nigeria (1989), Senegal (1963), and Togo (1979). Many developing nations have signed and ratified human rights treaties. Cf. A. M. Solarz, "Prawa człowieka i etyka w stosunkach międzynarodowych," Polski Przeglad Dyplomatyczny 1 (2007), 71. 
one form of apologetics that favor the human person and the rights that are due to him. ${ }^{49}$

\section{The Integrality of Human Rights}

Their integral nature of human rights is closely connected with the dignity of the human person. ${ }^{50}$ Hence the fundamental purpose of human rights is to safeguard man's dignity in the social, political, economic and cultural realities of contemporary life. This protection guarantees man's social rights, solidary rights, and his right to be free. These rights are important because they are the source of human existence. $^{51}$

Universal human rights have an individual dimension with regard to man's ability to meet his basic needs as an individual (e.g., the right to life, freedom, education, etc.) and fulfill his basic human and social needs (e.g., the right to associate, participate in political life, and choose the structure of one's country, etc.). ${ }^{52}$

When he spoke to the United Nations in 1979, John Paul II presented a detailed list of human rights. He included: the right to life, to freedom, personal security, food, clothing, housing, health care, rest and recreation, freedom of speech, education, culture, freedom of thought, conscience, religion, individual and communal—private and public religious expression, a particular status or profession, establish a family by providing the conditions necessary for the development of family life, property and work, decent working conditions, fair remuneration for work, freedom of assembly, freedom to move within and outside one's country, nationality and residence, participate in political life, and the right to freely choose the political system of the state to which it belongs. ${ }^{53}$ This list covers the basic needs of man as an individual and social being, and it is similar to the list that Pope John XXIII mentioned in the encyclical Pacem in terris. However, John Paul II added several new rights to it-namely: the right to personal security, fair

49 Cf. R. Czekalski, Godność osoby ludzkiej. Nauczanie Jana Pawła II (Warsaw: BEL Studio Sp. z o.o., 2007), 112.

Cf. John Paul II, Address to the Diplomatic Corps "Kościół współczesnego świata w służbie wielkiej sprawy (01.14.1980)," in DZ, Vol. V (Cracow: Wydawnictwo M, 2007), 451. świata," 463. 
play, nationality, and freely choose one's political system. ${ }^{54}$ By mentioning this list of fundamental human rights, the Pope desired to show the international community the laws that should be guaranteed in every state. However, good will is also necessary and a prerequisite for introducing, applying, and respecting these rights. ${ }^{55} \mathrm{John}$ Paul II also emphasized that, "[w]hen the violation of any fundamental human right is accepted without reaction, all other rights are placed at risk." ${ }^{56}$

According to the pope, international law should protect human rights. These rights should be in accord with the principles of natural and moral law, respect the convictions of believers as full members of the community, and give them the opportunity to speak and participate in public debates, which guarantee international order. If based on these foundations, international law cannot be used by stronger states to justify shameful acts and to impose their own policies on other states or international organizations. ${ }^{57}$

Human dignity is always the foundation of the integrity of human rights and serves as the normative basis of laws-a basis that is not the result of social contracts, the historical development of social relations, or the establishment of power. Human rights do not depend on the establishment of power or society. Rather, they supersede and precede particular individuals, societies, and states ${ }^{58}$ Human rights are innate because they arise from the fact that man is human; they are an integral part of his nature. The creator of human right is not man, but man's creator: God. Therefore, these rights exist and are granted to men throughout their lives. Even though many international institutions may disagree about the supernatural origin of human rights, "[t] he inviolability of human rights consists in the fact that no authority or community can take these rights away from man." ${ }^{59}$ Human rights

$54 \quad$ Cf. M. Mokrzycki, "Nauczanie społeczne Jana Pawła II w aspekcie praw człowieka," 37 Cykl: Wykłady otwarte Wyższej Szkoty Zarzadzania i Administracji w Zamościu (Zamość: Centrum Badawczo-Szkoleniowe Wyższej Szkoły Zarządzania i Administracji w Zamościu, 2008), 12-13.

Cf. John Paul II, Address to the Diplomatic Corps "Oby wszyscy odkryli miłość Ojca wszechświata (01.11.1999)," in DZ, Vol. V (Cracow: Wydawnictwo M, 2007), 595-596.

John Paul II, Message on the $32^{\text {nd }}$ World Day of Peace "Poszanowanie praw człowieka warunkiem i źródłem prawdziwego pokoju (01.01.1999)," in DZ, Vol IV (Cracow: Wydawnictwo M, 2007), 813.

Cf. John Paul II, Oby wszyscy odkryli miłość Ojca wszechświata, 595.

Cf. "Prawa człowieka," in ENS, 394. Katolickiego Uniwersytetu Lubelskiego, 1994), 390-391. 
are inalienable, which means that no human person can give them up or renounce them: "[t]he inalienability of human rights arises directly from that they are innate and from God." ${ }^{60}$ Their inviolability and nontransferability make them permanent and immutable. These rights are vested in man regardless of his position in society, sex, race, and place and time in which he has or will live on the earth. According to John Paul II, a person acquires personal rights at the moment of his conception. Hence the first and most important of the human rights is the right to life, which should respected at every single stage ${ }^{61}$ The law best expresses human dignity and other human rights, and it should be a constitutive element of society and its legislation. ${ }^{62}$

\section{The Primacy of Human Rights Over State Laws}

Basic human rights are a source of community, civil, and political rights. These laws mutually influence and depend on each other. "When the rights of the citizen are not respected, it is almost always to the detriment of fundamental human rights," "63 revealing, according to John Paul II, the primacy of human rights over the laws of the state. The personal and social dimension of human rights is of indispensable value for any modern society that should respect and protect it; "[t]hese values must be maintained and fostered in society, otherwise they also risk disappearing from the texts of the law." ${ }^{64}$

Man must be the essential criterion according to which international life is determined. In the modern world, the importance of the individual has increased along with efforts to represent the individual's interests. These interests transcend the borders of many countries and confirm the primacy of human rights over the laws of the state. Despite the existence of laws meant to protect human rights, man and his rights are still subject to threats. Therefore, it is necessary to take

60 T. Borutka and A. Zwoliński, Katolicka nauka społeczna (Częstochowa: Wydawnictwo Paulinianum, 1999), 47.

61 Cf. John Paul II, "Integracja europejska na fundamencie wspólnych wartości," OsRomPol 1 (2003): 41.

62 Cf. Catechism of the Catholic Church (Vatican City, Italy: Libreria Editrice Vaticana, 1997), 2273.

63 John Paul II, Address to the Diplomatic Corps "Transcendentne podstawy godności i praw człowieka (01.09.1989)," in DZ, Vol. V (Cracow: Wydanictwo M, 2007), 525. For the address in English, see: https://w2.vatican.va/content/johnpaul-ii/en/speeches/1989/january/documents/hf_jp-ii_spe_19890109_corpodiplomatico.html.

64 Ibid, 526. 
Catholic socia teaching

measures to protect human rights in threatening situations. The most important threats to human rights that must be resolved are tensions and conflicts. ${ }^{65}$ In order to avoid these conflicts, it is necessary to reflect on the events of the past; for, as the pope emphasized, those who look to the future without having drawn conclusions from the past will not be able to find the path of understanding. For example, many states still consider armed struggle to be the only effective means to demonstrate the justness of their cause. Consequently, nations and states resort to violence and destroy the achievements of societies and trample international law and humanitarian conventions underfoot in order to more effectively control their enemies. From John Paul II's point of view, mutual reconciliation and understanding as an act of goodwill on the part of the parties involved are the most important step to be taken in this matter. In this way, each nation can recognize the rights of the other nation(s). ${ }^{66}$

One of the most important goals of international institutions should be to prevent and resolve conflicts and restore peace through solutions that guarantee the rights and interests of all parties. ${ }^{67}$ According to John Paul II, the activities of international institutions only make sense when "the human dimension is made the principal concern, in a world made by man and for man." 68 However, these activities should be enacted with ideological neutrality, respect for human dignity as the foundation of human rights, belief in the primacy of the person over society, respect for democratically recognized norms, and acceptance of the pluralism of social structures without which a sustainable international order can not be established..$^{69}$ In this matter, it is also necessary to respect the natural and supernatural character of human rights without which a society worthy of man cannot be created. This

65 Cf. John Paul II, Address to the Diplomatic Corps "Wojna i ubóstwo: dwie plagi nękające ludzkość (01.16.1993)," in DZ, Vol. V (Cracow: Wydawnictwo M, 2007), 561. For the address in English, see: https://w2.vatican.va/content/john-paul-ii/en/ speeches/1993/january/documents/hf_jp-ii_spe_19930116_corpo-diplomatico. html.

Cf. John Paul II, Address to the Diplomatic Corps "Narody mają prawo do wyboru własnego sposobu myślenia i życia (01.11.1992)," in DZ, Vol. V (Cracow: Wydawnictwo M, 2007), 548.

Cf. E. Kaczyński, Moje spotkania z Janem Pawtem II (Warsaw: Instytut Wydawniczy Pax, 2008), 74. John Paul II, "Wojna i ubóstwo: dwie plagi nękające ludzkość," 561.

69 Cf. John Paul II, Address to the Diplomatic Corps "Europa i świat na progu ostatniej dekady XX wieku (01.13.1990)," in DZ, Vol V (Cracow: Wydawnictwo M, 2007), 530 . 
pertains to the situation where man has made himself the exclusive measure of all things without reference to the laws of God. In this situation, man to becomes a slave to his own limitations and abilities. ${ }^{70}$

The issue of the primacy of human rights over the laws of the state has contributed to the creation of a uniform system of protection of human rights. Two historical periods have had an immediate impact on this system's creation. The first was the interwar period, during which the protection of human rights was part of the internal competence of states. This effort failed on many levels, however, because it was impossible to create a compact system at that time. ${ }^{71}$ The second and decisive period was during World War II. At that time, human rights were routinely violated, especially by the states of the totalitarian regimes. As a result, there was a need for a unified and coherent international human rights system. The most important aim of this system was to protect humanity from the tragedies that they had experienced thus far. ${ }^{72}$ As a result of these two periods in history, many legal acts and documents were drafted. The most important of these are: the Universal Declaration of Human Rights (December 10, 1948) (33 $^{73}$

Cf. Ibid.

71 During the interwar period, the League of Nations took certain actions to uphold and protect the human rights, particularly of children, refugees, and national minorities. At that time, however, it did not create a consistent system of legal norms regarding human rights, nor did it develop effective ways to implement these norms. In practice, the League of Nations has not created a so-called "regime of protection of human rights" by which we can understand a set of (un)clearly, expressed principles, norms, rules and decision-making procedures to which people who are acting and relating on an international level can refer and resort. Cf. M. Żmigrodzki, ed., "Reżimy międzynarodowe," in Encyklopedia politologii, Tom. 5: Stosunki międzynarodowe, ed., T. Łoś-Nowak (Zakamycze: Kantor Wydawniczy Zakamycze, 2002), 320.

Cf. F. J. Mazurek, Prawa człowieka, 188. The author emphasizes how respect for human rights was unsatisfactory during that period of history, and developing countries were unable to guarantee their citizens the ability and freedom to exercise these rights. For this reason, there is an urgent need to work toward protecting human rights on an international level.

73 The Universal Declaration of Human Rights was an ethical manifesto and not legally binding. However, the fact that the nation states agreed on and accepted the document, which was the first of its kind devoted entirely to the issue of human rights, reveals that it an exceptionally important document for the development of international law and ethics. In this way, while not legally binding for the nation states, the document served as the source of law for the organization in which it was enacted and, therefore, had a decisive influence on the work of the United. Cf. A.M. Solarz, "Prawa człowieka i etyka," 67. 
Catholic social teaching

and the European Convention on Human Rights (November 4, 1950). ${ }^{74}$ These documents confirmed that human rights are inalienable and inviolable-that man cannot renounce these rights and that no power can deprive man of these rights. These laws limited state power by defining the limits of action. This does not mean, however, that state authority is not involved in proclaiming and upholding these rights and that the development of social and economic relations does not affect their articulation and defense. Rather, it means that the power of the state often helps proclaim, protect, and affirm these human rights. ${ }^{75}$

Human rights are granted regardless of whether or not they are published in state constitutions or international conventions. For, these rights constitute a person's position in society and define a person's development in relation to other people, social groups, and institutions. In this way, human rights function similarly to social principles and rules. The human person as well as natural and supernatural human dignity are their common points of reference. ${ }^{76}$

Diplomacy should be particularly interested in the unique position of human rights, since these rights belong to oppressed nations fighting for liberation and self-determination. Diplomats must fight for a better life, education, and medical care for ethnic minorities who are the subject of racism and discrimination. After the dramatic events of World War II, human rights extended beyond interstate relations and into the international arena. The respect due to human rights has become a global problem as evidence by the universalization of human rights. ${ }^{77}$

\section{The Holy See and the Protection of Human Rights}

In his teaching to diplomats, John Paul II emphasized the Holy See's involvement in protecting human rights. ${ }^{78} \mathrm{He}$ taught that "the Holy

74 John Paul II, Address to the participants of the Council of Europe Conference of Ministers "Wartości religijne i moralne wspólnym dziedzictwem (11.03.2000)," in DZ, Vol. XIV (Cracow: Wydawnictwo M, 2009), 845.

Cf. F. J. Mazurek, "Prawo do pracy w encyklice," in Jan Pawet II, Laborem exercens. Powotany do pracy, ed. J. Krucina (Wrocław: 1983), 201.

76 Cf. J. Majka, Etyka życia gospodarczego (Wrocław: Wrocławskiej Księgarni Archidiecezjalnej, 1982), 29-30.

77 Cf. F. J. Mazurek, Prawa człowieka, 5.

78 Cf. Ibid, 235. The Magisterium of the Church promotes human rights and raises awareness every human person's entitlement to them through papal social encyclicals, the Second Vatican Council's documents, synodal documents, papal speeches and messages, and in the pastoral letters of particular episcopates. 
See addresses all people, regardless of their ideology, and desires to defend the inviolable rights of human dignity, regardless of the civilization or its mentality."79 The papal assessment is a path that leads to openness to human expectations, affirmations, and anxieties. On this path, the Holy See commits itself to the protection of fundamental human rights. The social teaching of the Church defines these rights as natural, inalienable, inviolable, universal, supranational (absolute), dynamic, and subjective. These rights also have a communal dimension because man, on the one hand, can develop fully only in communion with other people, and, on the other hand, they can be realized through solidarity between all people and nations. ${ }^{80}$

Involvement in the defense of human rights is the duty and moral responsibility of the Holy See. "Man in the full truth of his existence, of his personal being and also of his community and social being-in the sphere of his own family, in the sphere of society and very diverse contexts, in the sphere of his own nation or people (perhaps still only that of his clan or tribe), and in the sphere of the whole of mankind-this

Popes have dealth either directly or indirectly with human rights in the following documents: Leo XIII in the encyclical Rerum Novarum (1891); Pius XI in the encyclical Quadragesimo anno (1931), Mit brennender Sorge (1937), Non abbiamo bisogno (1931), Divini illius Magistri (1929), Divini Redemptoris (1937); Pius XII in his radio address from December 24, 1942; John XXIII in the encyclical Mater et Magistra (1961), and above all in Pacem in terris (1963); Paul VI in Populorum Progressio (1967) and Octogesima adveniens (1971) and his letter addressed to Cardinal Roy, numerous speeches, and messages (addressed to the UN and on the occasion of the World Day of Peace); the Second Vatican Council in the constitution Gaudium et spes, in the declaration Dignitatis humane and Gravissimum educationis and the decree Inter mirificia; John Paul II in the encyclical Redemptor hominis (1979) and Laborem exercens (1981), Sollicitudo rei socialis (1987), numerous speeches delivered during his travels, and messages (including those delivered at the UN headquarters and on the occasion of the World Day of Peace). The Synod of Bishops in Rome promulgated the documents De iustitia in mundo (1971) and Human Rights and Reconciliation (1974). The Pontifical Commission "Iustitia et Pax"promulgated three documents: The Church and Human Rights (1974), The General Theme of Human Rights (1974) and the Economic Justice for All (1986). The bishops of international episcopates have dedicated lot of attention to the human rights in their pastoral letters. For example, letters of the Polish Episcopate, the Latin American Episcopate (Medellin in 1968 and Puebla in 1979) and the letter of the North American Bishops' Conference on the prohibition of the use of nuclear weapons (1983), as well as Economic Justice for All (1987).

John Paul II, "Kościół wobec największych problemów współczesnego świata," 463.

80 Cf. J. Kondziela, "Chrześcijańskie ujęcie praw człowieka na tle dyskusji międzynarodowej," Chrześcijanin w świecie 63-64 (1978), 55. 
Catholic social teaching man is the primary route that the Church must travel in fulfilling her mission: he is the primary and fundamental way for the Church, the way traced out by Christ himself." 81 This explains the Holy See's concern for a man as an individual who is called to social life.$^{82}$ Reflection on human rights takes into account what causes and constitutes their violation. This reflection, however, it is not detached from reality and current social, economic, cultural or political situations. ${ }^{83}$ For example, within the communist system, man was treated like a "cog in a machine." 84 The Holy See has repeatedly defended captive men by teaching about man's dignity and rights regardless of whether this dignity and rights were and are recognized by the state. ${ }^{85}$

In showing the Holy See's involvement in the defense of human rights, John Paul II recognized the role that diplomacy plays in this issue. He believed that diplomacy's main aim should be the protection of man and his rights. In order to achieve this aim, it is helpful to seek the consent, cooperation, and respect of all parties involved.$^{86}$ The voice of the Church in this matter should be helpful. This is especially true of the evangelical principle of charity, which, as the most important feature of Christian life, should take on a universal dimension. ${ }^{87} \mathrm{~A}$ world based on the foundation of justice and respect for human rights can be formed on this principle. ${ }^{88}$ These values guarantee that peace is maintained and preserved in the world. ${ }^{89}$

$81 \quad$ John Paul II, "Encyklika Redemptor hominis Ojca Świętego Jana Pawła II. Odkupiciel człowieka, Rzym 1979," in DZ, Vol. I (Cracow: Wydawnictwo M, 2006), 14. For the encyclical in English, see: http://w2.vatican.va/content/john-paul-ii/ en/encyclicals/documents/hf_jp-ii_enc_04031979_redemptor-hominis.html.

Cf. John Paul II, "Kościół wobec największych problemów współczesnego świata," 463.

Cf. F. J. Mazurek, Prawa człowieka, 236.

Cf. J.Krukowski, Kościót i państwo (Lublin: Redakcja Wydawnictw Katolickiego Uniwersytetu Lubelskiego, 2000), 244.

Cf. Ibid.

Cf. John Paul II, Address to the Diplomatic Corps "Wyzwania stojące przed ludzkością: życie, chleb, pokój i wolność (01.10.2005)," in DZ, Vol. V (Cracow: Wydawnictwo M, 2007), 623.

Cf. John Paul II, Address to the Diplomatic Corps "Jak dobry Samarytanin z ewangelicznej przypowieści (04.03.1987)," OsRomPol 4 (1987): 24.

Cf. John Paul II, Address to the Diplomatic Corps "By pokój nie byt jedynie brakiem wojny (02.03.1985)," OsRomPol 3 (1985): 23. ludzkości (03.25.2000)," OsRomPol 5 (2000): 33. 
During his pilgrimage to Vilnius in 1993, John Paul II met with the Diplomatic Corps. Speaking to them, he stressed that more attention should be paid to formulating and defending human rights: "[T]rue interest of nations cannot be thought of solely in terms of political strategy or economic development." ${ }^{90}$ Rather, in order to form a new world order, it is necessary to establish internally consistent societies that respect the primordial values of justice, peace and human dignity. ${ }^{91}$

When speaking to the Committee of the Parliamentary Assembly of teaching the Council of Europe, Pope John Paul II stressed that the Holy See's efforts to protect of human rights have involved making the international community aware of the need to protect these rights. ${ }^{92}$ The World Conference on Human Rights that took place in Vienna in 1993 was one of the most important events to influence the world's understanding of human rights issues. The purpose of this conference was to assess what had been achieved thus far with regard to international protection of human rights and freedoms and to promote worldwide cooperation in universally recognizing these rights and freedoms. This made it possible convince people worldwide that international law guarantees international order. It must do so, however, based on permanent moral principles (human rights) that effectively limit actions against its maintenance. ${ }^{93}$

The need to secure human rights has prompted many international institutions to develop relevant legislation that will do so. The most important forms of legislation achieved thus far are the Charter of Fundamental Rights, the Convention for the Protection of Human Rights and Fundamental Freedoms, and the European Social Charter. These documents established the limits of the inviolability of these rights. ${ }^{94}$ Therefore, the mission of the Holy See is to help all those who suffer from social, economic, political, and armed conflicts, as well as various injustices and violations of fundamental human rights. The Church is willing to collaborate with leaders of states or those who appeal for the Holy See's collaboration to seek and find the right solutions to emerging problems. The Holy See is not influenced by political or economic interests with regard to human rights violations, however.

\footnotetext{
90 John Paul II, “Zadania dyplomatów w nowej sytuacji Europy,” 15.

$91 \quad$ Cf. Ibid.

92 Cf. John Paul II, “O podstawową tożsamość Europy,” 838.

$93 \quad$ Cf. John Paul II, “Wizja świata zjednoczonego,” 21.

94 Cf. John Paul II, Address to the leaders of the Parliament of the European Union "Stużyć dobru wspólnemu (09.23.2000)," in DZ, Vol. XIV (Cracow: Wydawnictwo M, 2009), 843.
} 
Rather, the Holy See uses diplomatic means to preserve and protect human dignity and rights..$^{95}$

\section{Diplomatic Responses to Papal Teaching}

Catholic social teaching

The Pope's teaching on human rights received widespread attention from diplomats. Many of them personally emphasized how efforts to promote and protect human rights are very beneficial to the international community.

For example, when speaking about threats to human rights, Paul Ndiaye, Ambassador of Senegal to the Holy See, said that constructive dialogue between parties is the only way to overcome misunderstandings and conflicts.$^{96}$ Likewise, Edward Tsu-yu Wu, China's Ambassador to the Holy See, emphasized that peace and justice should be promoted in every corner of the world..$^{97}$

A.A. Peralta, Costa Rica's Ambassador to the Holy See, emphasized all states should be interested in the protection of human rights. According to this ambassador, any action taken in this regard helps to promote peace throughout the world. The ambassador mentioned his country as an example; Costa Rica has a rich and noble history, which from its inception has guarded human rights. The edifying vision of the country's ancestors and its spiritual values are the source of such attitudes. Among Costa Rica's fundamental goals as a nation is respect for human rights in a historical and international context. ${ }^{98}$

The Canadian Ambassador to the Holy See, T. Arcand, shared a similar reflection. According to him, the state of the modern world depends on its level of respect for human rights; their promotion and

$95 \quad$ Cf. John PaulII, Meeting with the Diplomatic Corps "Kościótpragnie wspótdziałać w ratowaniu godności ludzi i narodów (05.12.1985)," OsRomPol numer nadzwyczajny I (1985): 9.

$96 \quad$ Cf. P. Ndiaye, "Ambassador of Senegal," in Papal Diplomacy: John Paul II and the Culture of Peace, ed. B. J. O'Connor (South Bend, Indiana: St. Augustine's Press, 2005), 183-184.

97 Cf. E. Tsu-yu Wu, "Ambassador of China," in Papal Diplomacy: John Paul II and the Culture of Peace, ed. B. J. O'Connor (South Bend, Indiana: St. Augustine's Press, 2005), 234.

98 Cf. A.A. Peralta, "Ambassador of Costa Rica," in Papal Diplomacy: John Paul II and the Culture of Peace, ed. B. J. O'Connor (South Bend, Indiana: St. Augustine's Press, 2005), 186. 
protection make it possible to build a better future.$^{99}$ Vigniko A. Amedegnato, Ambassador of Togo, noted that the development, recognition, respect, and protection of human rights is difficult in places where a large proportion of the population is deprived and suffering from hunger, disease, and death. ${ }^{100}$

Mark Pellew, Ambassador of the United Kingdom, stated that the European Convention on Human Rights was established thanks to the efforts of the international community. This convention made it possible for Her Majesty's government to incorporate its norms into British law. Pellew emphasized that the basic aim of the convention was to unify basic rights and freedoms and that that the United Kingdom was one of the first countries to embrace the need to apply and respect human rights in every dimension of social life in its foreign policy. ${ }^{101}$

Ketel Borde, the Ambassador of Norway, said that the international community appreciates and admires the Holy See's commitment to the promotion and protection of human rights. For, this activity makes people realize that improving the living conditions of millions of people is possible due to the proper respect for basic human rights. ${ }^{102}$

Stefan Frankiewicz, Ambassador of Poland, stated that the freedom that Poland recovered in 1989 is also due to the Holy See. Thanks to the Holy See's commitment to the defense of human rights, it has become possible to shape "the order of communal life on the firm foundation of universal values, the primacy of the person over society, the dignity of every person as the source of human rights, and the deepest link between politics and culture." 103

By analyzing papal teaching on human rights to diplomats, B. O'Connor, the author of Papal Diplomacy, said that there should be a platform for understanding and cooperation among nations, and Pope

99 Cf. T. Arcand, "Ambassador of Canada," in Papal Diplomacy: John Paul II and the Culture of Peace, ed. B. J. O'Connor (South Bend, Indiana: St. Augustine's Press, 2005), 225.

100 Cf. V.A. Amedegnato, "First Ambassador of Togo," in Papal Diplomacy: John Paul II and the Culture of Peace, ed. B. J. O'Connor (South Bend, Indiana: St. Augustine's Press, 2005), 196.

101 Cf. M. Pellew, "Ambassador of Great Britain and Northern Ireland," in Papal Diplomacy: John Paul II and the Culture of Peace, ed. B. J. O'Connor (South Bend, Indiana: St. Augustine's Press, 2005), 246.

102 Cf. K. Borde, "Ambassador of Norway," in Papal Diplomacy: John Paul II and the Culture of Peace, ed. B. J. O'Connor (South Bend, Indiana: St. Augustine's Press, 2005), 209.

103 Cf. S. Frankiewicz, Ambassador Stefan Frankiewicz's speech "Polska zdaje egzamin z trudnej wolności (07.11.1995)," OsRomPol 8-9 (1995): 44-45. 
Catholic social teaching

John Paul II shows how diplomatic means can be used to achieve this greater understanding and cooperation among nations. Basic human rights, such as the right to life and freedom of religion and conscience, are the cornerstones of human rights. They lead to a nation's development, strengthen its legislation, and shape its future. ${ }^{104}$

The diplomats' response to papal teaching with regard to human rights has shaped the conviction that human rights must be respected. This conviction is now one of the most important aims of diplomacy, since human rights help maintain international order and shape the moral work of diplomacy.

\section{Summary}

Clearly Pope John Paul II believed that diplomats have a moral duty to ensure respect for human rights. It is for this reason that John Paul II creatively developed the issue of human rights in his teaching to them. Specifically, his teaching called for the principle of human rights, which should be applied both within states and internationally; serve as the determinant of true humanism in social, economic, political and cultural spheres; and be based on relations between states. In this way, human rights eliminate all forms of imperialism, exploitation, and colonialism from international life and help maintain and strengthen international order.

In order for principle of human rights to flourish, it is necessary to overcome emerging threats to human rights. The escalation of tensions generates fear, aggression, violence, and hatred, which subsequently turn into conflicts. Cultural, ideological or political differences are the foundation of many conflicts. The unjust distribution of material goods is a source of business and economic differences. For this reason, Pope John Paul II called on the diplomats to take decisive and concrete actions to protect human rights, specifically by diffusing tensions and conflicts and ensuring the just distribution of material goods. ${ }^{105}$ The solutions to these problems are possible only when they are based on a proper understanding of the inherent nature of human rights. Only when human rights are treated as an integral whole can they fulfill their mission to protect the welfare of man and society. If these rights are treated selectively, then they become subordinated to the defense

104 Cf. B.J. O'Connor, Papal Diplomacy: John Paul II and the Culture of Peace (South Bend, Indiana: St. Augustine's Press, 2005), 330-338.

105 Cf. J. Grosfeld, "Wstęp do encykliki Sollicitudo rei socialis,” in DZ, Vol. I (Cracow: Wydawnictwo M, 2006), 277. 
of the particular interests of particular groups or institutions. In turn, these groups and institutions ultimately deny the fundamental role of human rights in the international arena. ${ }^{106}$

John Paul II also emphasized that human rights are superior to and precede society and the state. The roots of democracy are precisely in the inviolable rights of every human being, which are universal and pertain to every person regardless of differences, gender, race, worldview, or religion. No man can be deprived of human rights, even if for various reasons he lives on the margins of society. This applies especially to those who voluntarily oppose the norms of social life, are temporarily or permanently isolated by society, as well as those who, through no fault of their own, are among the weakest and most needy due to complex personal, economic, or social factors. For John Paul II, respect for the rights of the marginalized is a clear test of diplomacy, which should serve as an example of respect for rights and justice. The absolute nature of human rights is also expressed in their inviolability and inalienability, which means that no circumstance, institution, or declaration can deprive man of his natural rights. Even man himself cannot deny his own human rights. ${ }^{107}$

The reflections of individual diplomats shows that papal teaching on human rights has sparked a lively debate, the result of which is the conviction that diplomacy's most important task is to promote and defend human rights. Diplomatic activities in this area help maintain international order and develop moral responsibility for the fate of man and the world. A lack of respect for human rights creates many moral problems. Therefore, diplomats agree that human rights are universal and inseparable and that the whole international community should work towards their integral development in a spirit of solidarity. ${ }^{108}$

When speaking of human rights, John Paul II paid special attention to those who are obligated to preserve them, bring them to life, and always use them to serve the common good of society and respect the rights of others. Although human rights are permanently integrated into cultures, they are not given to man once and for all. In this regard, the Holy Father pointed to many situations in which the temptation to violate human rights is still great and the fact that the world in which man lives is still a place of injustice and oppression. Human rights are

106 Cf. K. Gryz, "Wstęp do orędzi i przesłań poświęconych prawom człowieka," in DZ, Vol. V (Cracow: Wydawnictwo M, 2007), 282.

107 Cf. Ibid.

108 Cf. G. Galassi, Address to the dean of the Diplomatic Corps "Ojcze Święty, potrzebujemy Ciebie (01.10.2003)," OsRomPol 3 (2000): 27. 
Catholic social teaching

a challenge that every human being and the international community must face so that these rights can be more and more consciously based on an authentic anthropological foundation and on unequivocal moral norms and rooted in various national, cultural, and religious traditions.

During almost every meeting with diplomats, Pope John Paul II appealed for respect for human rights and encouraged them to determine whether established laws truly serve the human person in all of his dimensions in both practice and theory. ${ }^{109}$ In addition, the pope pointed out trends that lead to paralysis and disruption: "The decline in the rate of marriages and births, the many ways in which human life is attacked, the spread of drug abuse, the displays of self-centeredness on the part of individuals, families and communities-all these appear to be symptoms of a destructive skepticism and lack of confidence in life and the future." 110

For John Paul II, respect for human rights is, on the one hand, a suitable platform for dialogue with the world and, on the other hand, a way to introduce Christian values into contemporary culture. John Paul II respected all diplomatic activities aimed at promoting human rights. One of the most important (but not the only) examples of respect for human rights on the part of the international community was the General Assembly of the United Nations' signing of the Universal Declaration of Human Rights in 1948. For the pope, this event was a great milestone in human development. Papal teaching to diplomats reveals that Pope John Paul II wanted to make an original contribution to efforts to promote and protect human rights. And, the Christian message clearly formulated in the Gospel mission itself was his inspiration.

\section{POSZANOWANIE PRAW CZŁOWIEKA MORALNĄ POWINNOŚCIĄ DYPLOMACJI W ŚWIETLE NAUCZANIA JANA PAWŁA II}

Prawa człowieka zajmują istotne miejsce w nauczaniu Jana Pawła II do dyplomatów. Podstawą refleksji na temat praw człowieka dla Papieża jest godność osoby ludzkiej. Papież w nauczaniu do dyplomatów przedstawiał sposób rozumienia, ujmowania i wyjaśniania praw człowieka. Celem niniejszej

109 Cf. A. Koprowski, "Wprowadzenie do przemówień do organizacji międzynarodowych,” in DZ, Vol. XIV (Cracow: Wydawnictwo M, 2009), 813.

110 John Paul II, Address to the Democratic Group of European Parliament "Klimat życzliwości jest konieczny do rozwoju współpracy (11.13.1980)," in DZ, Vol. XIV (Cracow: Wydawnictwo M, 2009), 831. For the address in English, see: https:// w2.vatican.va/content/john-paul ii/en/speeches/1980/november/documents/ hf_jp_ii_spe_19801113_democratici-europei.html. 
publikacji jest ukazanie, że poszanowanie praw człowieka to moralna powinność dyplomacji. Respektowanie praw człowieka jest dla Papieża z jednej strony odpowiednią płaszczyzną do prowadzenia dialogu ze światem, z drugiej strony - drogą do wprowadzania wartości chrześcijańskich we współczesną kulturę. Jan Paweł II szanował wszelkie działania dyplomacji, których celem była promocja praw człowieka.

Słowa kluczowe: prawa człowieka, dyplomacja, Jan Paweł II.

\section{Bibliography:}

1. Amedegnato, V.A. "First Ambassador of Togo." In Papal Diplomacy: John Paul II and the Culture of Peace. Edited by B. J. O'Connor. South Bend, Indiana: St. Augustine's Press, 2005, 195-196.

2. Arcand, T. "Ambassador of Canada." In Papal Diplomacy: John Paul II and the Culture of Peace. Edited by B. J. O'Connor. South Bend, Indiana: St. Augustine's Press, 2005, 224-225.

3. Borde, K. "Ambassador of Norway." In Papal Diplomacy: John Paul II and the Culture of Peace. Edited by B. J. O'Connor. South Bend, Indiana: St. Augustine's Press, 2005, 209-210.

4. Borutka, T., and A. Zwoliński. Katolicka nauka społeczna. Częstochowa: Wydawnictwo Paulinianium, 1999.

5. Czekalski, R. Godność osoby ludzkiej. Nauczanie Jana Pawła II. Warsaw: Wydawnictwo BEL Studio Sp. z o.o., 2007.

6. Frankiewicz, S. Address by Stefan Frankiewicz "Polska zdaje egzamin z trudnej wolności (July 11, 1995)." L'Osservatore Romano. Polish Edition 8-9 (1995): 44-45.

7. Galassi, G. Address of the Head of the Diplomatic Corps "Ojcze Święty, potrzebujemy Ciebie (January10, 2003).” L'Osservatore Romano. Polish Edition 3 (2000): 27-28.

8. Grosfeld, J. "Wstęp do encykliki Sollicitudo rei socialis." In Dzieła zebrane Jana Pawta II. Vol. I. Cracow: Wydawnictwo M., 2006, 277-279.

9. Gryz, K. "Wstęp do orędzi i przesłań poświęconych prawom człowieka." In Dzieła zebrane Jana Pawła II. Vol. V. Cracow: Wydawnictwo M, 2007, 281-283.

10. John Paul II. John Paul II, “By pokój nie był jedynie brakiem wojny (02.03.1985)." L'Osservatore Romano. Polish Edition 3 (1985): 23.

11. John Paul II. Meeting with the Consulate General in Jerusalem "Dla dobra ludzkości (03.25.2000)." L'Osservatore Romano. Polish Edition 5 (2000): 33.

12. John Paul II. "Encyklika Redemptor hominis Ojca Świętego Jana Pawta II. Odkupiciel człowieka, Rzym 1979.” In Dzieła zebrane Jana Pawła II. Vol I. Cracow: Wydawnictwo M, 2006, 24-62.

13. John Paul II. Address to the Diplomatic Corps "Europa i świat na progu ostatniej dekady XX wieku (01.13.1990)." Dzieła zebrane Jana Pawta II. Vol. V. Cracow: Wydawnictwo M, 2007, 528-535. 
14. John Paul II. Speech to the new ambassador of Beglium "Integracja europejska na fundamencie wspólnych wartości (11.31.2003).” L'Osservatore Romano. Polish Edition 1 (2003): 40-41.

15. John Paul II. Address to the Diplomatic Corps "Jak dobry Samarytanin z ewangelicznej przypowieści (04.03.1987)." L'Osservatore Romano. Polish Edition 4 (1987): 23-24.

16. John Paul II. Address to the Democratic Group of European Parliament "Klimat życzliwości jest konieczny do rozwoju współpracy (11.13.1980)." Dzieła zebrane Jana Pawta II. Vol. XIV. Cracow: Wydawnictwo M, 2009, 831.

17. John Paul II. Meeting with the Diplomatic Corps "Kościót pragnie wspótdziałać $w$ ratowaniu godności ludzi $i$ narodów (05.12.1985)." L'Osservatore Romano. Polish Edition, numer nadzwyczajny I (1985).

18. John Paul II. Address to the Diplomatic Corps "Kościół wobec największych problemów współczesnego świata (01.16.1982)." In Dzieła zebrane Jana Pawta II. Vol. V. Cracow: Wydawnictwo M, 2007, 461-471.

19. John Paul II. Address to the Diplomatic Corps "Kościół współczesnego świata w służbie wielkiej sprawy (01.14.1980)." In Dzieła zebrane Jana Pawta II. Vol. V. Cracow: Wydawnictwo M, 2007, 447-452.

20. John Paul II. Address to the General Assembly of the United Nations "Na forum pokoju i sprawiedliwości (10.02.1979)." In Dzieła zebrane Jana Pawta II. Vol. XIV. Cracow: Wydawnictwo M, 2009, 24-34.

21. John Paul II. Address to the Diplomatic Corps "Narody maja prawo do wyboru własnego sposobu myślenia i życia (01.11.1992)." In Dzieła zebrane Jana Pawta II. Vol. V. Cracow: Wydawnictwo M, 2007, 546-553.

22. John Paul II. Address to the Diplomatic Corps "Nie ma dnia do stracenia (01.14.1984)." In Dzieła zebrane Jana Pawta II. Vol. V. Cracow: Wydawnictwo M, 2007, 481-486.

23. John Paul II. Address to the Diplomatic Corps "Nie' śmierci, egoizmowi i wojnie! 'Tak' życiu i pokojowi! (01.13.2003).” In Dzieła zebrane Jana Pawta II. Vol. V. Cracow: Wydawnictwo M, 2007, 613-617.

24. John Paul II. Address to the Diplomatic Corps "Oby wszyscy odkryli miłość Ojca wszechświata (01.11.1999).” In Dzieła zebrane Jana Pawła II. Vol. V. Cracow: Wydawnictwo M, 2007, 592-596.

25. John Paul II. Address to the Diplomatic Corps "Od czego zależy prawdziwy i trwały pokój (01.09.1988 r.)." In Dzieła zebrane Jana Pawła II. Vol. V. Cracow: Wydawnictwo M, 2007, 513-520.

26. John Paul II. Address to the Parliamentary Assembly Committee of the European Council for Relations with National Parliaments "O podstawową tożsamość Europy (03.17.1988).” In Dzieła zebrane Jana Pawła II. Vol. XIV. Cracow: Wydawnictwo M, 2009, 838-839.

27. John Paul II. Speech during a meeting with the Canadian government and the Diplomatic Corps at Rideau Hall "O nową wizję ludzkości (09.19.1984).” In Dzieta zebrane Jana Pawta II. Vol. XII. Cracow: Wydawnictwo M, 2009, 235-238.

28. John Paul II. Address to the Diplomatic Corps "Otwórzmy serca i umysły na wyzwania naszych czasów (01.10.2002)." In Dzieła zebrane Jana Pawta II. Vol. V. Cracow: Wydawnictwo M, 2007, 608-612. 
29. John Paul II. Speech given at the headquarters of the International Court of Justice in Hague "O wspólne dobro społeczności międzynarodowej (05.13.1985)." In Dzieła zebrane Jana Pawta II. Vol. XIV. Cracow: Wydawnictwo M, 2009, 740-745.

30. John Paul II. Address to the Diplomatic Corps "Pokój nie jest możliwy bez solidarności i sprawiedliwości (01.11.1986)." In Dzieła zebrane Jana Pawta II. Vol. V. Cracow: Wydawnictwo M, 2007, 496-505.

31. John Paul II. Message on the $32^{\text {nd }}$ World Day of Peace "Poszanowanie praw człowieka warunkiem i źródłem prawdziwego pokoju (01.01.1999)." In Dzieła zebrane Jana Pawta II. Vol. IV. Cracow: Wydawnictwo M, 2007, 807-814.

32. John Paul II. Address to the leaders of the Parliament of the European Union "Stużyć dobru wspólnemu (09.23.2000)." In Dzieła zebrane Jana Pawła II. Vol. XIV. Cracow: Wydawnictwo M, 2009, 843-844.

33. John Paul II. Address to the Diplomatic Corps "Stolica Apostolska jest głosem, na który czeka ludzkie sumienie (01.09.1995)." In Dzieła zebrane Jana Pawta II. Vol. V. Cracow: Wydawnictwo M, 2007, 572-576.

34. John Paul II. Address to the Diplomatic Corps "Stolica Apostolska wobec problemów ludzkości (01.12.1981).” In Dzieła zebrane Jana Pawła II. Vol. V. Cracow: Wydawnictwo M, 2007, 453-460.

35. John Paul II. Address to the new ambassador of Holland "Szacunek dla osoby ludzkiej od poczęcia do naturalnej śmierci (01.22.2005).” L'Osservatore Romano. Polish Edition 4 (2005): 20-21.

36. John Paul II. Address to the Diplomatic Corps "Światła i cienie współczesnego świata (01.13.1996)." In Dzieła zebrane Jana Pawta II. Vol. V. Cracow: Wydawnictwo M, 2007, 577-582.

37. John Paul II. Address to the Diplomatic Corps "Transcendentne podstawy godności i praw człowieka (01.09.1989)." In Dzieła zebrane Jana Pawła II. Vol. V. Cracow: Wydawnictwo M, 2007, 521-527.

38. John Paul II. Address to the participants of the Council of Europe Conference of Ministers "Wartości religijne i moralne wspólnym dziedzictwem (11.03.2000)." In Dzieła zebrane Jana Pawła II. Vol. XIV. Cracow: Wydawnictwo M, 2009, 845-846.

39. John Paul II. Meeting with the Diplomatic Corps in Madrid "Wizja świata zjednoczonego (07.16.1993)." L'Osservatore Romano. Polish Edition 8-9 (1993): 21-22.

40. John Paul II. Message to the Secretary General of the United Nations "Wolność religijna podstawą praw ludzkich (12.02.1978)," In Dzieła zebrane Jana Pawła II. Vol. V. Cracow: Wydawnictwo M, 2007, 285-287.

41. John Paul II. Address to the Diplomatic Corps "Wojna i ubóstwo: dwie plagi nękające ludzkość (01.16.1993)." In Dzieła zebrane Jana Pawła II. Vol. V. Cracow: Wydawnictwo M, 2007, 554-562.

42. John Paul II. Address to the Diplomatic Corps “Wszyscy jesteśmy odpowiedzialni za wszystkich (01.10.2000).” In Dzieła zebrane Jana Pawła II. Vol. V. Cracow: Wydawnictwo M, 2007, 597-601. 
Catholic social teaching
43. John Paul II. Address to the Diplomatic Corps "Wyzwania stojące przed ludzkością: życie, chleb, pokój i wolność (01.10.2005)." In Dzieła zebrane Jana Pawta II. Vol. V. Cracow: Wydawnictwo M, 2007, 622-627.

44. John Paul II. Address to the Diplomatic Corps "Założenia i cele międzynarodowej działalności Stolicy Apostolskiej (01.15.1983).” In Dzieła zebrane Jana Pawła II. Vol. V. Cracow: Wydawnictwo M, 2007, 472-480.

45. John Paul II. Meeting with the Diplomatic Corps in Vilnius "Zadania dyplomatów w nowej sytuacji Europy (09.05.1993)." L'Osservatore Romano. Polish Edition 12 (1993): 14-16.

46. Jasionek, S. Prawa człowieka. Cracow: Wydawnictwo WAM, 2004.

47. Kaczyński, E. Moje spotkania z Janem Pawłem II. Warsaw: Instytut Wydawniczy Pax, 2008.

48. Kaczorowski, B., Ed. Nowa encyklopedia powszechna PWN. Vol. 6. Warsaw: Wydawnictwo Naukowe PWN SA, 2004.

49. Kondziela, J. "Chrześcijańskie ujęcie praw człowieka na tle dyskusji międzynarodowej." Chrześcijanin w świecie 63-64 (1978): 49-59.

50. Koprowski, A. "Wprowadzenie do przemówień do organizacji międzynarodowych." In Dzieła zebrane Jana Pawła II. Vol 14. Cracow: Wydawnictwo M, 2009, 811-815.

51. Krukowski, J. Kościót i Państwo. Podstawy relacji prawnych. Lublin. Redakcja Wydawnictw Katolickiego Uniwersytetu Lubelskiego, 2000.

52. Ndiaye, P. “Ambassador of Senegal." In Papal Diplomacy: John Paul II and the Culture of Peace. Edited by B. J. O'Connor. South Bend, Indiana: St. Augustine's Press, 2005, 183-184.

53. Majka, J. Etyka życia gospodarczego. Wrocław: Wrocławskiej Księgarni Archidiecezjalnej, 1982.

54. Mazurek, F.J. "Prawo do pracy w encyklice." Jan Pawet II, Laborem exercens. Powołany do pracy. Edited by J. Krucina. Wrocław: 1983, 201-228.

55. Mazurek, F. J. Prawa człowieka w nauczaniu społecznym Kościoła (od papieża Leona XIII do papieża Jana Pawła II). Lublin: Redakcja Wydawnictwo Katolickiego Uniwersytetu Lubelskiego, 1991.

56. Mokrzycki, M. "Nauczanie społeczne Jana Pawła II w aspekcie praw człowieka." 37 Cykl: Wykłady otwarte Wyższej Szkoty Zarzadzania i Administracji w Zamościu. Zamość: Wyd. Centrum Badawczo-Szkoleniowe Wyższej Szkoły Zarządzania i Administracji w Zamościu, 2008.

57. O'Connor, B.J. Papal Diplomacy: John Paul II and the Culture of Peace. South Bend, Indiana: St. Augustine's Press, 2005.

58. Osmańczyk, E.J., Ed. Encyklopedia spraw międzynarodowych $i$ ONZ. Warsaw: Państwowe Wydawnictwo Naukowe, 1974.

59. Osmańczyk, E.J., Ed. Encyklopedia ONZ i stosunków międzynarodowych. Warsaw: Wiedza Powszechna, 1986.

60. Pellew, M. "Ambassador of Great Britain and Northern Ireland." In Papal Diplomacy: John Paul II and the Culture of Peace. Edited by B. J. O'Connor. South Bend, Indiana: St. Augustine's Press, 2005, 246-248.

61. Peralta, A.A. "Ambassador of Costa Rica." In Papal Diplomacy: John Paul II and the Culture of Peace. Edited by B. J. O'Connor. South Bend, Indiana: St. Augustine's Press, 2005, 186-187. 
62. Solarz, A.M. "Prawa człowieka i etyka w stosunkach międzynarodowych." Polski Przeglad Dyplomatyczny 1 (2007): 63-89.

63. Strzeszewski, C. Katolicka nauka społeczna, Lublin: Redakcja Wydawnictw Katolickiego Uniwersytetu Lubelskiego, 1994.

64. Tsu-yu Wu, E. "Ambassador of China." In Papal Diplomacy: John Paul II and the Culture of Peace. Edited by B. J. O'Connor. South Bend, Indiana: St. Augustine's Press, 2005, 233-234.

65. Zwoliński, A., Ed. Encyklopedia nauczania społecznego Jana Pawła II. Radom: Wydawnictwo Polwen, 2005.

66. Żmigrodzki, M., Ed. Encyklopedia politologii, Tom. 5: Stosunki międzynarodowe. Edited by T. Łoś-Nowak. Zakamycze: Wydawnictwo Kantor Wydawniczy Zakamycze, 2002. 